\title{
Mortality from accidents, disease, suicide and homicide in the British fishing industry from 1900 to 2010
}

\author{
Stephen E. Roberts ${ }^{1}$, Tim Carter ${ }^{2}$ \\ ${ }^{1}$ Medical School, Swansea University, Singleton Park, Swansea, United Kingdom \\ ${ }^{2}$ Norwegian Centre for Maritime Medicine, Haukeland University Hospital, University of Bergen, Norway
}

\begin{abstract}
Background: To establish the causes of mortality in the British fishing industry from 1900 up to 2010, to investigate long term trends in mortality and to identify causal factors in the mortality patterns and rates. Materials and methods: A longitudinal study, based on examinations of official death inquiry files, marine accident investigation files and reports, death registers and annual death returns.

Results: Mortality rates from accidents while working at sea remain high in the British fishing industry. Over the twentieth century there has been a progressive fall in the numbers of deaths, much of this relates to changes in fishing methods and in the types of vessels used. However in recent years, and with a fleet of smaller vessels, the mortality rates from accidents have shown little change and a larger proportion of deaths than in the past have arisen from personal injuries and drowning as compared to vessel losses. Disease makes a relatively small contribution to mortality at sea and this has dwindled with the decline in distant water fishing. Suicide and homicide both feature in a small way, but rates cannot readily be compared with those ashore.

Conclusions: The pattern of change in vessels, fisheries and fishing techniques over the study period are complex. However, improved injury and drowning prevention is the most important way to reduce deaths, coupled with attention to vessel stability and maintenance. The social, economic and organisational features of the fishing industry mean that securing improvements in these areas is a major challenge.
\end{abstract}

(Int Marit Health 2015; 66, 4: 211-219)

Key words: mortality, accidents, disease, suicide, homicide, fishing industry

\section{INTRODUCTION}

Previous studies have reported on trends in mortality from fatal accidents in fishing fleets from countries including Alaska, Britain, Denmark, Iceland, Norway, Poland and the United States, mostly during the last 30 or 40 years [1-9]. Reports on the Alaskan, Icelandic, Norwegian, Polish (trawler) and United States fishing fleets have reported large or moderate reductions over time in fatal accident rates while studies of Danish, British and Polish (small-scale) fishing have reported little or no improvement. This contrasts with trends in fatal accidents in merchant shipping which have usually fallen sharply over time [10]. There have been few reports on long term trends in fatal accidents in fishing industries dating back over the twentieth century and also few reports on mortality rates from disease, suicide and homicide in fishing industries.

The British fishing fleet has witnessed many changes over the twentieth century. These are important when interpreting changes over time in patterns and rates for fatalities. Changes include the early reductions in the numbers of sailing vessels and an increase in larger steam drifter trawlers up to the 1940s, followed by a move to motor fishing vessels. Fishing techniques changed from drift net to trawl net fishing and then from side trawlers to larger, more stable stern trawlers, sometimes with on board fish processing and factory freezing. The major 'distant water'

Dr Stephen Roberts, Medical School, Swansea University, Singleton Park, Swansea SA2 8PP, United Kingdom, e-mail: stephen.e.roberts@swansea.ac.uk 
trawler fleet, which often operated in treacherous conditions in the Barents Sea, around Bear Island or Iceland, declined sharply during the late 1970s. Recently, the British fishing industry has used a diverse pattern of smaller-scale fishing techniques, including potting, dredging and line fishing, often with their own particular hazards. With quota restrictions and economic pressures, crewing levels in these smaller fishing vessels have dwindled and lone fishing has increased.

The main objectives of this study were, firstly, to establish the causes of mortality in the British fishing industry from 1900 up to 2010, secondly, to investigate long term trends in mortality and, thirdly, to identify causal factors in the mortality patterns and rates.

\section{MATERIALS AND METHODS}

The principal marine accident investigative authority in Britain has been the Marine Accident Investigation Branch since 1989. It is notified of and investigates fatal accidents that occur in the British fishing industry. The Registry of Shipping (previously the Registrar General for Shipping and Seamen) was responsible, under the Merchant Shipping Act of 1894 [11], for registering deaths that occurred at sea among British nationals and from British maritime vessels, including fishing vessels as well as merchant ships.

Details of all fatalities in the British fishing industry were obtained from 1989 onwards, through examination of marine accident investigation files and reports held at or provided by the Marine Accident Investigation Branch. From 1976 onwards, they were also identified through examination of paper death inquiry files and death registers held at the Registry of Shipping. For earlier years, annual death returns based on the files at the Registry of Shipping were published variously by the Board of Trade, the Department of Trade and Industry, the Department of Industry and the Department of Trade [12-16]. The returns were released or could be located for all years except those covering 1900 to $1908,1912,1915$ to 1918 while the populations of fishermen employed were not available for the years from 1939 to 1946 . Hence, mortality and population information was available for 89 years out of the 111 years studied. Mortality from disease was also not available from 2006 to 2010 and mortality from suicide and homicide was not distinguished from 1919 to 1939 and was not available from 2006 to 2010 . Further details of fishing vessel casualties were obtained through the Hull Trawler website [17], reports of marine investigations including Marine Accident Investigation Branch reports, and earlier 'wreck reports' from the "Port Cities - Southampton" website [18]. Information was also provided by members of the "Ships nostalgia" website [19], and found through other searches. The population was exclusively a male one for most fisheries and periods, hence it is appropriate to use the term 'fishermen'.
The study included all deaths among full-time or part-time commercial fishermen while they were employed in British registered fishing vessels, but excluded deaths among "hobby" fishermen, who do not fish commercially. Fatal accidents were distinguished according to whether they involved an accident or incident to the fishing vessel - fishing vessel casualties or disasters - or were personal accidents involving individual fishermen. Deaths from unexplained disappearances at sea and drowning from alcohol or drug intoxication were included with personal accidents. Fatalities that occurred during leave periods were not included and it is likely that some deaths from disease or injuries that arose at sea but where there was a prolonged period of hospitalisation ashore went unrecorded. Other fatal illnesses ashore that had a prolonged course, even if it was work related, would also not be recorded if the person had ceased to work in fishing, for example to take up less demanding work ashore.

The populations of fishermen employed annually in the British fishing industry were obtained from annual returns produced by the Board of Trade, the Department for Environment, Food and Rural Affairs, the Ministry of Agriculture, Fisheries and Food, the Ministry of Agriculture and Fisheries and the Board of Trade [12, 20-22]. The fishermen were conventionally counted as if they had been employed for the whole of each year. Over the 89 study years with both mortality and population information, there was a total population of 2.76 million fishermen-years at risk in the British fishing industry. The number of fishermen employed fell from 105,349 in 1909 to 29,011 in 1938 and from 45,555 in 1947 to less than 25,000 by the late 1960 s. After fluctuating between 20,000 and 25,000 from the late 1960s to the early 1990s, since 1994 the workforce has fallen almost every year to 12,647 in 2010 .

Annual mortality rates in the fishing industry were based on the numbers of deaths and divided by the populations of fishermen at risk and were expressed per 100,000 population. Spearman's rank correlations were used to assess changes in mortality rates over time with significance measured at the conventional $5 \%$ level.

\section{RESULTS}

Based on the study inclusion and exclusion criteria, over the 89 study years, there was a total of 6,448 fatalities in the British fishing industry. 5,439 (84.4\%) of the fatalities were caused by accidents, of which 3,108 arose from casualties to the vessel and 2,331 were from personal accidents. The remaining fatalities were attributed to disease (921; 14.3\%), suicide $(77 ; 1.2 \%)$ and homicide $(11 ; 0.2 \%)$.

\section{MORTALITY FROM ACCIDENTS}

Figure 1 shows trends over time in the fatal accident rate in the British United Kingdom fishing industry, with highest 


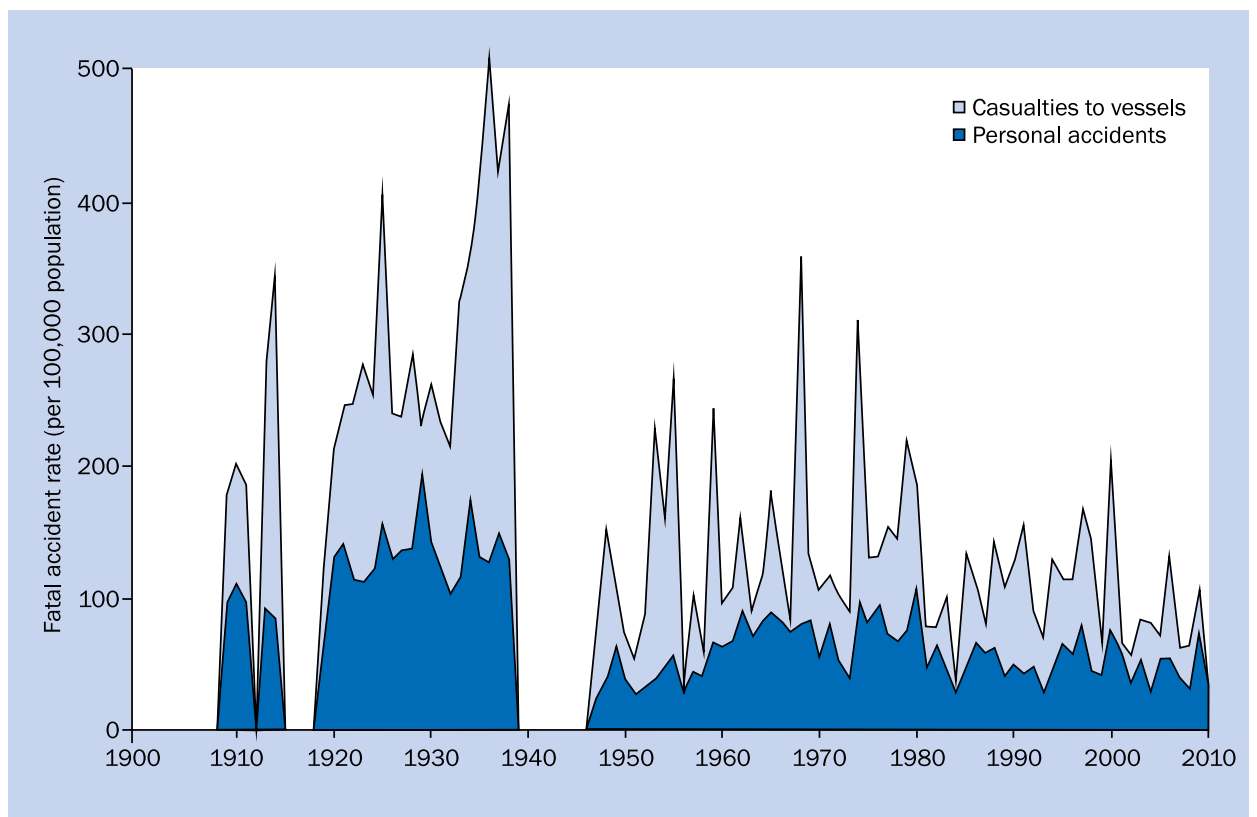

Figure 1. Trends in the fatal accident rate in the British fishing industry

levels of fatal accidents apparent during the 1920s and 1930s, which increased from the earlier years from 1909 to 1914. There was a peak in the fatal accident rate during the mid and late 1930s caused largely by the disappearance, foundering or stranding of large distant water trawlers, usually operating around Bear Island or Iceland, Greenland, the Barents Sea or the White Sea. These include the Loch Ard (13 fatalities in 1934), the Jeria and the Langanes (28 lost, 1935), the Admiral Collingwood (18 lost, 1936), the Amethyst (18 fatalities, 1937), the Lady Lavinia and the St. Sebastien (32 lost, 1938).

The fatal accident rate was reduced from the 1940s onwards, although peaks in the fatality rate continued to follow major disasters involving large distant water trawlers. These include 1948 when the trawlers Goth, Sargon and Epine grounded or foundered off Iceland during storms with 46 men lost. In 1955 the 2 Hull trawlers Lorella and Roderigo disappeared off North Cape, Iceland on the same night with 40 men lost after the deck structures iced over during snow blizzards and hurricane force winds. In 1959 the Fleetwood trawler Red Falcon disappeared in storms off the west coast of Scotland with 20 men when returning from Arctic fishing. In 1968, during a 3 week period in January and February, another 4 Hull trawlers St. Romanus, Kingston Peridot and Ross Cleveland were lost with 58 men, the latter 2 during snow blizzards and severe weather off Iceland. In 1974, the Hull trawler Gaul disappeared with 36 men in the Barents Sea.

The fatal accident rate has remained fairly constant at around 100 per 100,000 fishermen-years during the last
40 years with no discernible trend since 1947 (correlation $=-0.18 ; p=0.15$ ). Table 1 provides details of major fishing disasters involving the loss of 5 or more fishermen during the 51 year period from 1960 to 2010. Of the major disasters that have arisen in recent years, the Arosa grounded near Galway Bay, west Ireland with 12 fatalities, the scallop dredger Solway Harvester foundered in the Irish Channel (7 lost) and the Pescalanza capsized off Mizen Head, south west Ireland (6 lost). Photographs of 8 of the fishing trawlers that have been lost with 158 fishermen since the 1950s are shown in Figure 2.

Figure 3 shows trends over time in the fatal accident rate from 1919 according to the main type of fishing vessel casualty. Since the earlier years of the twentieth century, this shows more of a reduction over time in fatalities from grounding or stranding and also from fires and explosions but little decline for foundering (including capsize after snagged gear, categorised from 1976 onwards) or collisions.

\section{MORTALITY FROM DISEASE, SUICIDE AND HOMICIDE}

Trends in mortality from disease, suicide and homicide, while at sea in the British fishing industry are shown in Figure 4 . Since 1947, there have been reductions over time in mortality rates from disease $(p<0.001)$, suicide $(p=$ $=0.012)$ and homicide $(p=0.044)$. From the available study information, mortality from disease increased sharply from about 20 per 100,000 fishermen-years during the years $1909-1914$ to around 40 per 100,000 in the early 1920s. It then increased sharply during the late 1920 s to a peak of 
Table 1. Details of major fishing disasters that led to the loss of five or more fishermen in the British fishing industry, 1960-2010

\begin{tabular}{|c|c|c|c|c|}
\hline Year & $\begin{array}{l}\text { Name of } \\
\text { vessel }\end{array}$ & $\begin{array}{l}\text { Type of vessel } \\
\text { (construction material, } \\
\text { gross tonnage and age) }\end{array}$ & $\begin{array}{l}\text { No. of } \\
\text { fisher- } \\
\text { men } \\
\text { lost }\end{array}$ & Details of the fishing casualty \\
\hline 2000 & $\begin{array}{l}\text { Solway } \\
\text { Harvester }\end{array}$ & Scallop dredger (steel, 49, 8) & 7 & $\begin{array}{l}\text { Capsized and foundered with all crew after gear and catch } \\
\text { shifted during bad weather in the Irish Sea. }\end{array}$ \\
\hline 2000 & Arosa & Side trawler (steel, 248, 26) & 12 & $\begin{array}{l}\text { Grounded and sank during F10 storms off the west coast of } \\
\text { Ireland. One survivor scrambled ashore. }\end{array}$ \\
\hline 1998 & Pescalanza & Side trawler (steel, 202, 30) & 6 & $\begin{array}{l}\text { Capsized and foundered during hauling-in operations in gales off } \\
\text { SW Ireland. }\end{array}$ \\
\hline 1998 & Silvery Sea & $\begin{array}{l}\text { Seine net trawler } \\
\text { (steel, 266, 22) }\end{array}$ & 5 & $\begin{array}{l}\text { Sank with all crew after a collision with a German container ship } \\
\text { in the North Sea off Denmark. }\end{array}$ \\
\hline 1994 & Larissa & Beam trawler (steel, 361, 19) & 6 & $\begin{array}{l}\text { Foundered with all crew after a collision with a Maltese bulk } \\
\text { carrier in the North Sea. }\end{array}$ \\
\hline 1992 & $\begin{array}{l}\text { Ocean } \\
\text { Hound }\end{array}$ & Beam trawler (steel, 43, 7) & 5 & $\begin{array}{l}\text { Sank following a collision with an unidentified vessel in fog } \\
\text { in the English Channel off Kent. All crew lost. }\end{array}$ \\
\hline 1991 & Wilhelmina J & Beam trawler (steel, 82, 25) & 6 & $\begin{array}{l}\text { Foundered with all hands following a collision with a Cyprus } \\
\text { general cargo ship in the English Channel. }\end{array}$ \\
\hline 1991 & Pescado & Beam trawler (steel, 56, 35) & 6 & $\begin{array}{l}\text { Foundered with all crew after snagging gear off Cornwall in } \\
\text { moderate conditions (F5/6) with stability deficiencies. }\end{array}$ \\
\hline 1990 & Premier & Seine net trawler (steel, 68, 16) & 6 & $\begin{array}{l}\text { Capsized and sank with all crew after being swamped by heavy } \\
\text { seas in F10 storms off NE Scotland. }\end{array}$ \\
\hline 1989 & Majestic & Pair Trawler (steel, 100, 15) & 5 & $\begin{array}{l}\text { Capsized after snagging trawl gear on an underwater obstruction } \\
\text { off the Orkney Islands. Two survivors. }\end{array}$ \\
\hline 1989 & Destiny & $\begin{array}{l}\text { Other fishing vessel } \\
\text { (other, } 9,7)\end{array}$ & 6 & $\begin{array}{l}\text { Foundered with all crew after the vessel became holed during } \\
\text { gales and snow in the Firth of Clyde, west Scotland. }\end{array}$ \\
\hline 1985 & Bon Ami & Stern trawler (steel, 34, 16) & 6 & $\begin{array}{l}\text { Grounded on rocks off NW Scotland and sank during F8 gales } \\
\text { and in heavy seas. All crew lost. }\end{array}$ \\
\hline 1985 & Mhari L & Side trawler (steel, 50, 7) & 5 & $\begin{array}{l}\text { Capsized and foundered with all crew in the Irish Sea after nets } \\
\text { snagged an underwater obstruction. }\end{array}$ \\
\hline 1983 & Arcadia & Trawler (nk, 42, 26) & 5 & $\begin{array}{l}\text { Sank with all hands after striking rocks in poor visibility off NW } \\
\text { Scotland. }\end{array}$ \\
\hline 1981 & Celerity & Light trawler (wood, 42, 9) & 6 & $\begin{array}{l}\text { Foundered with all hands during F10 storms and heavy snow in } \\
\text { the Pentland Firth, off north Scotland. }\end{array}$ \\
\hline 1979 & $\begin{array}{l}\text { Ocean } \\
\text { Monarch }\end{array}$ & Trawler (wood, 46, 8) & 7 & $\begin{array}{l}\text { Foundered with all crew, swamped by heavy seas in severe F11 } \\
\text { storms in the North Sea off Fair Isle, NE Scotland. }\end{array}$ \\
\hline 1979 & $\begin{array}{l}\text { Margarethe } \\
\text { Bojen }\end{array}$ & Pair trawler (steel, 49, 3) & 6 & $\begin{array}{l}\text { Capsized and foundered after it was struck by a freak wave in the } \\
\text { North Sea. All crew lost. }\end{array}$ \\
\hline 1979 & Tarradale II & Seine net trawler (wood, 79, 9) & 7 & $\begin{array}{l}\text { Sank with all hands in F10 storms in the North Sea after } \\
\text { departing Peterhead for Norwegian fishing grounds. }\end{array}$ \\
\hline 1979 & Carinthia & Side trawler (wood, 39, 23) & 6 & $\begin{array}{l}\text { Disappeared with all crew during gales and rough seas off the } \\
\text { Noup, NW Scotland. }\end{array}$ \\
\hline 1978 & Enterprise & Pair trawler (wood, 59, 8) & 8 & $\begin{array}{l}\text { Foundered with all crew in storms and } 40 \text { foot seas in the North } \\
\text { Sea off Lerwick, after departing Fraserburgh. }\end{array}$ \\
\hline 1977 & $\begin{array}{l}\text { Boston Sea } \\
\text { Ranger }\end{array}$ & Stern trawler (steel, 171, 1) & 5 & $\begin{array}{l}\text { Foundered after heavy seas flooded the fish hold in the English } \\
\text { Channel. All crew lost. }\end{array}$ \\
\hline 1977 & Sapphire & Seine net trawler $(n k, 46,22)$ & 5 & $\begin{array}{l}\text { Stranded and sank with all hands in poor visibility off the NW } \\
\text { coast of Scotland. }\end{array}$ \\
\hline 1974 & Gaul & $\begin{array}{l}\text { Stern factory trawler } \\
\text { (steel, 1,106, 2) }\end{array}$ & 36 & $\begin{array}{l}\text { Disappeared with all crew during storms in the Barents Sea. } \\
\text { Thought to have been swamped by heavy seas. }\end{array}$ \\
\hline 1974 & Trident & $\begin{array}{l}\text { Seine net trawler } \\
\text { (steel, } 110,4)\end{array}$ & 7 & $\begin{array}{l}\text { Disappeared with all crew off north Scotland. Thought to have } \\
\text { swamped by heavy seas, stability questioned. }\end{array}$ \\
\hline 1972 & Nautilus & Seine net trawler (nk, nk, nk) & 7 & $\begin{array}{l}\text { Foundered with all crew during gales in the North Sea, south of } \\
\text { Shetland. }\end{array}$ \\
\hline 1971 & Dinas & Side trawler (steel, 439, 15) & 5 & $\begin{array}{l}\text { A fire in the crew accommodation area, Irish Sea soon after } \\
\text { departing Fleetwood for Icelandic fishing grounds. }\end{array}$ \\
\hline 1970 & Rosebud II & Trawler (wood, nk, 15) & 7 & $\begin{array}{l}\text { Grounded and foundered in heavy weather off the Isle of Mull, } \\
\text { west Scotland. All crew lost. }\end{array}$ \\
\hline
\end{tabular}


Table 1. cont. Details of major fishing disasters that led to the loss of five or more fishermen in the British fishing industry, 1960-2010

\begin{tabular}{|c|c|c|c|c|}
\hline Year & $\begin{array}{l}\text { Name of } \\
\text { vessel }\end{array}$ & $\begin{array}{l}\text { Type of vessel } \\
\text { (construction material, } \\
\text { gross tonnage and age) }\end{array}$ & $\begin{array}{l}\text { No. of } \\
\text { fisher- } \\
\text { men } \\
\text { lost }\end{array}$ & Details of the fishing casualty \\
\hline 1969 & Coral Isle & $\begin{array}{l}\text { Seine net trawler } \\
\text { (steel, nk, 13) }\end{array}$ & 6 & $\begin{array}{l}\text { Disappeared with all six crew during severe gales in the North Sea } \\
\text { off Aberdeen. }\end{array}$ \\
\hline 1968 & $\begin{array}{l}\text { Kingston } \\
\text { Peridot }\end{array}$ & Side trawler (steel, 658, 21) & 20 & $\begin{array}{l}\text { Foundered with all crew when heading for shelter during severe } \\
\text { F9 gales off Iceland. }\end{array}$ \\
\hline 1968 & $\begin{array}{l}\text { Ross } \\
\text { Cleveland }\end{array}$ & Side trawler (steel, 659, 19) & 18 & $\begin{array}{l}\text { Foundered when sheltering from a F12 hurricane and snow } \\
\text { blizzards off Iceland. One survivor scrambled ashore. }\end{array}$ \\
\hline 1968 & St. Romanus & Side trawler (steel, 599, 19) & 20 & $\begin{array}{l}\text { Disappeared with all crew in the North Sea in F10 storms after } \\
\text { leaving Hull for the Barents Sea. }\end{array}$ \\
\hline 1968 & Refleurir & $\begin{array}{l}\text { Seine net trawler } \\
\text { (wood, nk, 40+) }\end{array}$ & 6 & $\begin{array}{l}\text { Foundered with all crew when heading for shelter during a sudden } \\
\text { storm off the north coast of Scotland. }\end{array}$ \\
\hline 1966 & St. Finbar & $\begin{array}{l}\text { Stern factory trawler } \\
\text { (steel, 1,139, 2) }\end{array}$ & 12 & $\begin{array}{l}\text { Fire and explosion in the accommodation area off the Labrador } \\
\text { coast, later foundered. } 13 \text { survivors. }\end{array}$ \\
\hline 1965 & $\begin{array}{l}\text { Boston } \\
\text { Pionair }\end{array}$ & Side trawler (steel, 103, 9) & 9 & $\begin{array}{l}\text { Disappeared with all hands during F10 storms in the North Sea } \\
\text { near Dogger Bank. }\end{array}$ \\
\hline 1965 & $\begin{array}{l}\text { Blue } \\
\text { Crusader }\end{array}$ & Side trawler (steel, 274, 7) & 13 & $\begin{array}{l}\text { Disappeared with all crew during a F12 hurricane off the east } \\
\text { coast of Orkney. }\end{array}$ \\
\hline 1962 & $\begin{array}{l}\text { Boston } \\
\text { Heron }\end{array}$ & Side trawler (steel, 314, 22) & 7 & $\begin{array}{l}\text { Grounded during severe F9 gales off the Western Isles, Scotland. } \\
\text { Five survivors. }\end{array}$ \\
\hline 1961 & Arctic Viking & Side trawler (steel, 533, 25) & 5 & $\begin{array}{l}\text { Capsized and sank during gales in the North Sea when returning } \\
\text { from the Barents Sea. } 14 \text { rescued from a life raft. }\end{array}$ \\
\hline
\end{tabular}

about 70 per 100,000 during the 1930s. At a much lower level during the late 1940s (30 per 100,000), it increased to over 50 per 100,000 during the 1960 s and subsequently fell sharply from the late 1970 s onwards. Information on suicide and homicide mortality was available mainly before 1919 and from the late 1940s onwards. Suicide mortality appears to have been fairly consistent at around 5 to 10 per 100,000 up to the 1960 s, peaking during the early 1970 s, with few suicides since the 1980s. Eleven homicides in the British fishing industry since the late 1940 s occurred mostly during the 1950s (6) and in the mid-1970s (2).

\section{DISCUSSION}

The study is one of the largest of mortality conducted for a maritime industry, covering more than 6,000 fatalities and a population of over 2.75 million fishermen-years. It is also based on information sources that were established to record vessel losses and fatalities at sea [11]. Limitations include the lack of available mortality or population information in the British fishing industry for some years during the 111 year study period. The reporting and recording of fatalities and registering of fishing vessels in the British fishing industry was unreliable before 1900 but slowly improved over the early years of the twentieth century. This is reflected in the relatively low mortality recorded before 1915 . The annual populations of fishermen employed were provided by successive governmental departments and agencies, their precision would have fluctuated over time. The ages of the populations of fishermen employed were not known for most years of the study period, preventing standardisation when reporting trends in mortality. This is of more importance for mortality from disease as changes over time may reflect differences in the ages of the fishermen employed, but is of less relevance to mortality from accidents, suicide and homicide which are related less clearly to age. However, the British fishing industry has always employed a high proportion of younger people, so that demographic profiles are unlikely to have altered greatly over the study period.

The increases in the fatal accident rate in the British fishing industry during earlier years of the twentieth century is linked partly to the coverage and recording of fatalities. The peak in the fatal accident rate during the 1920s and especially the 1930 s coincided with an expansion in distant water fishing and an economic depression. Following the resumption of full scale fishing activities in the late 1940s, the fatal accident rate was at a reduced level. Nonetheless, the large distant water fleet continued with fairly frequent major disasters involving large trawlers and major loss of life, sometimes in freezing snow blizzards, minimal visibility and storm force winds, usually around Iceland or in the Barents Sea [17-19, 23-26]. The build-up of freezing snow on trawler deck structures during prolonged storms was a particular hazard that threatened vessel stability. Remedial ice-hacking measures, themselves not without 


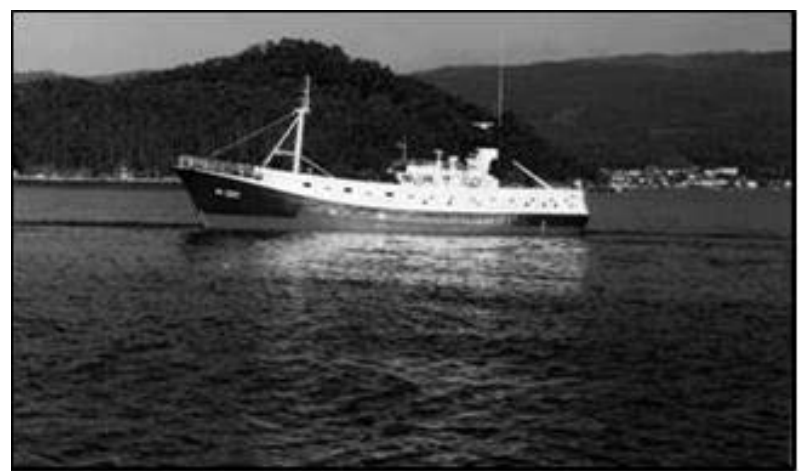

FV Arosa (2000)

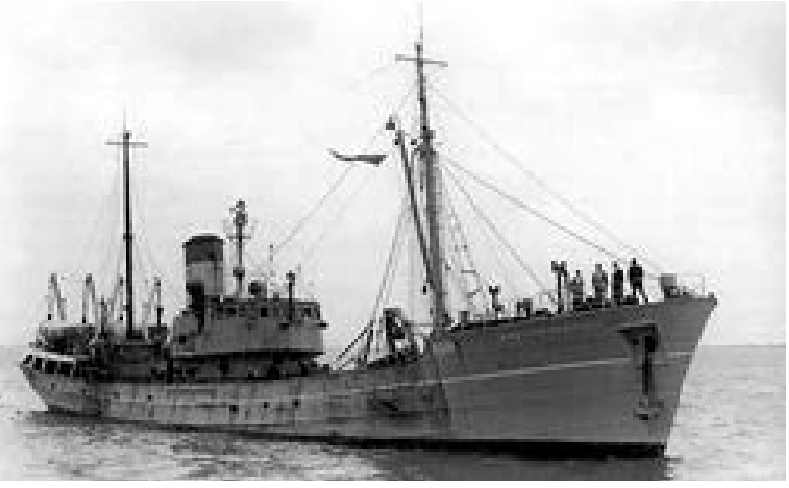

FV Kingston Peridot (1968)

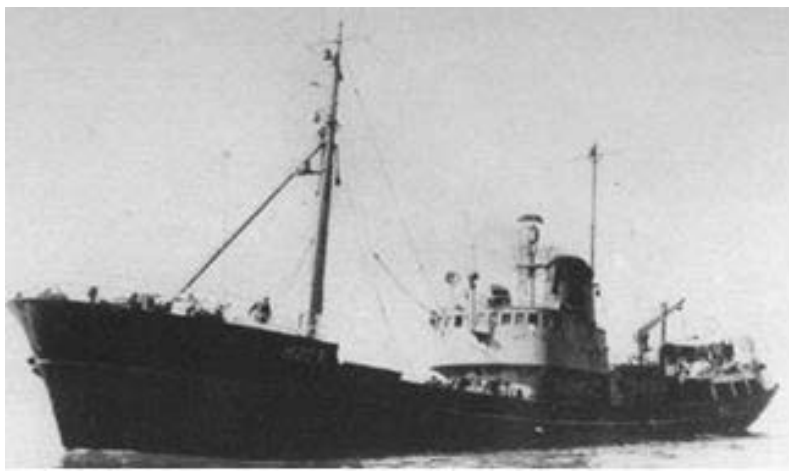

FV St. Romanus (1968)

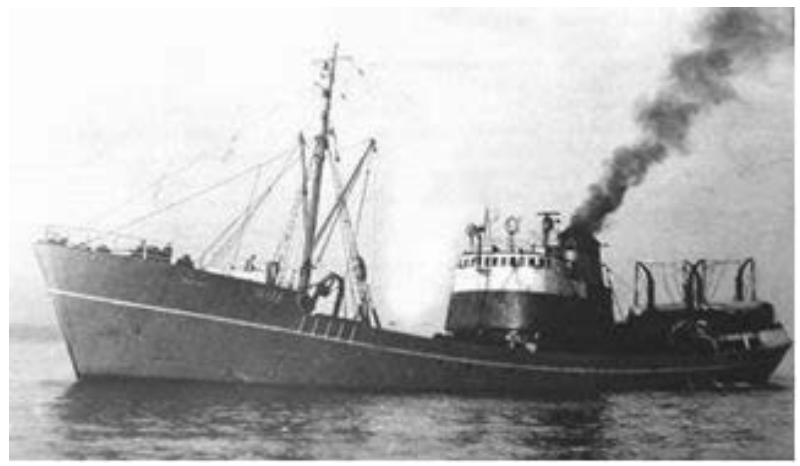

FV Roderigo (1955)

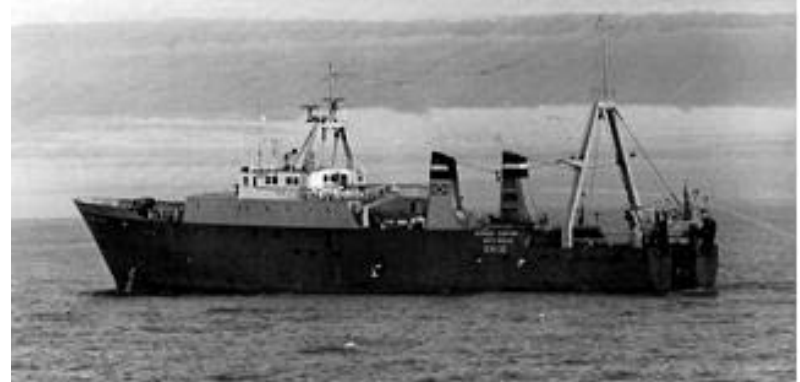

FV Gaul (1974)

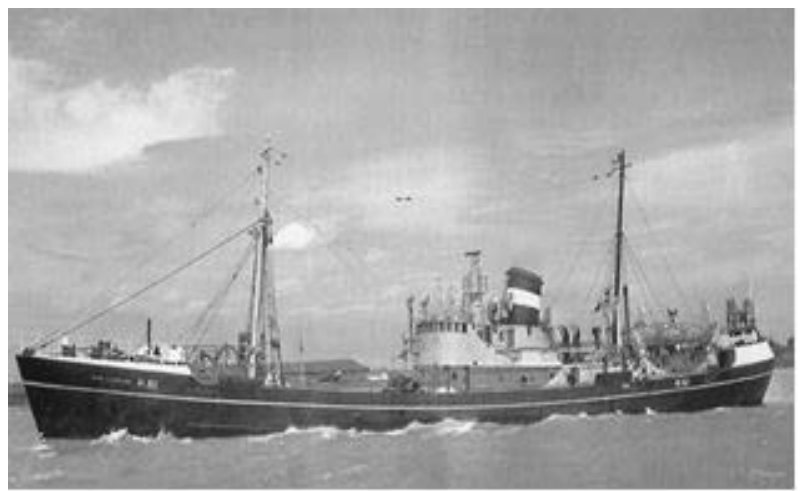

FV Ross Cleveland (1968)

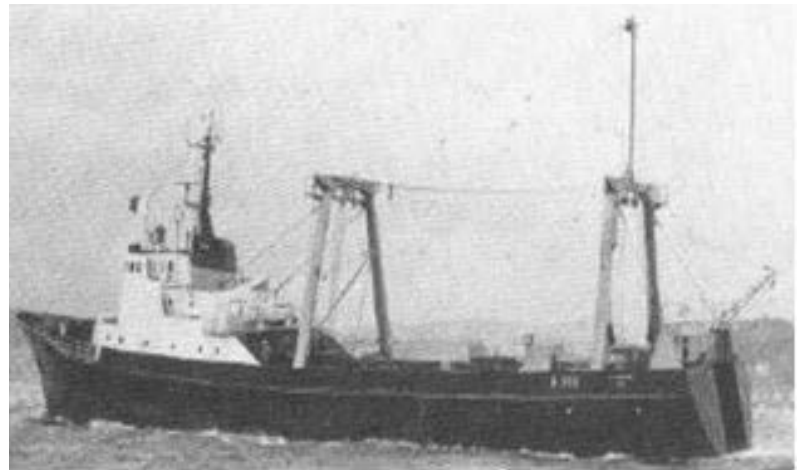

FV St. Finbar (1965)

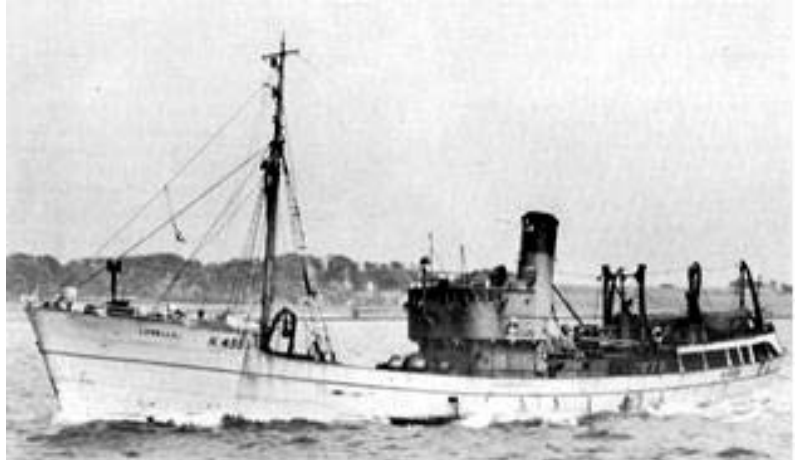

FV Lorella (1955)

Figure 2. Photographs of fishing vessels that were major casualties in the British fishing industry, 1947-2010, with year of disaster in brackets. 


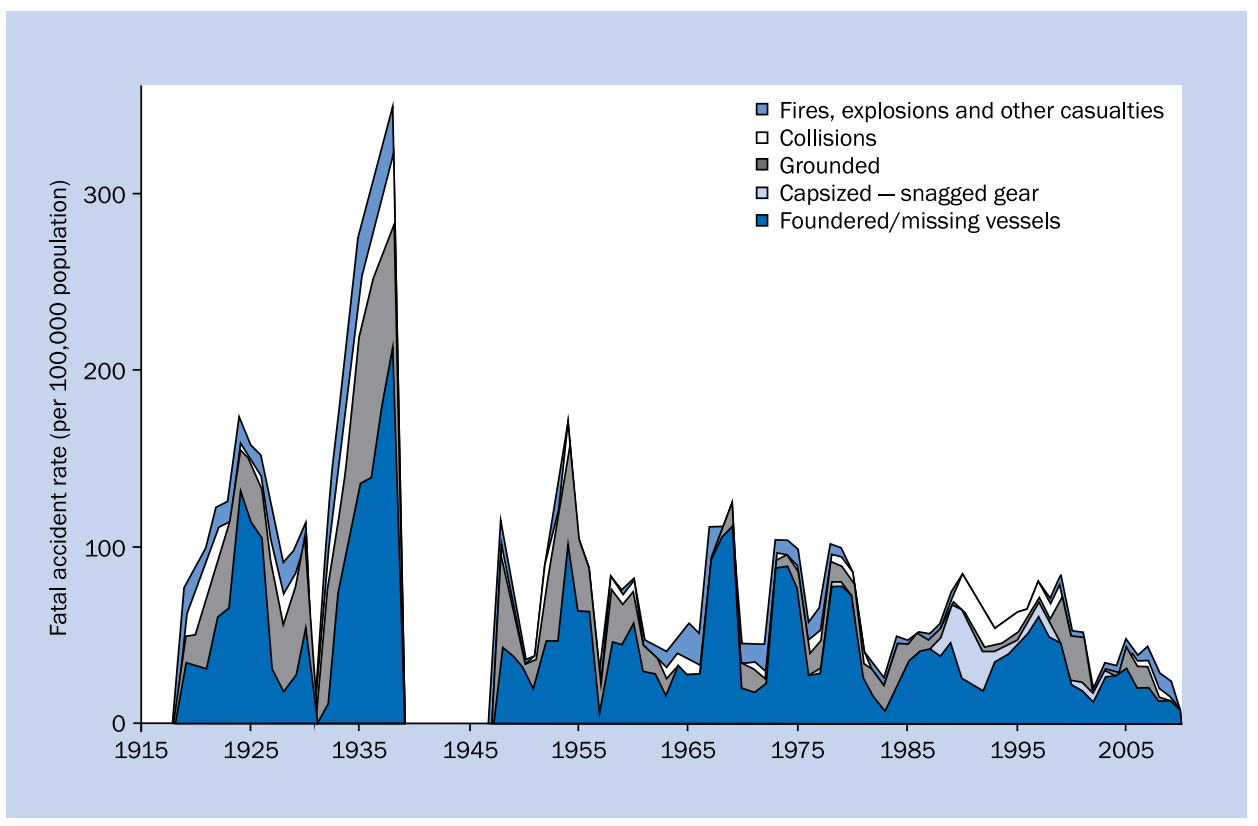

Figure 3. Trends in the fatal accident rate from fishing vessel disasters according to the type of disaster. Notes: The category "capsized - snagged gear" was not available before 1976. The category "fires, explosions and other casualties" was not available before 1919. Information on the type of casualty not available in 1931 as well as from 1915-1918 and 1939-1947. The fatal accident rates are smoothed using 3-year moving averages. From 1919 to 1939, this graph includes fatalities from casualties at sea but not from casualties in harbours and rivers.

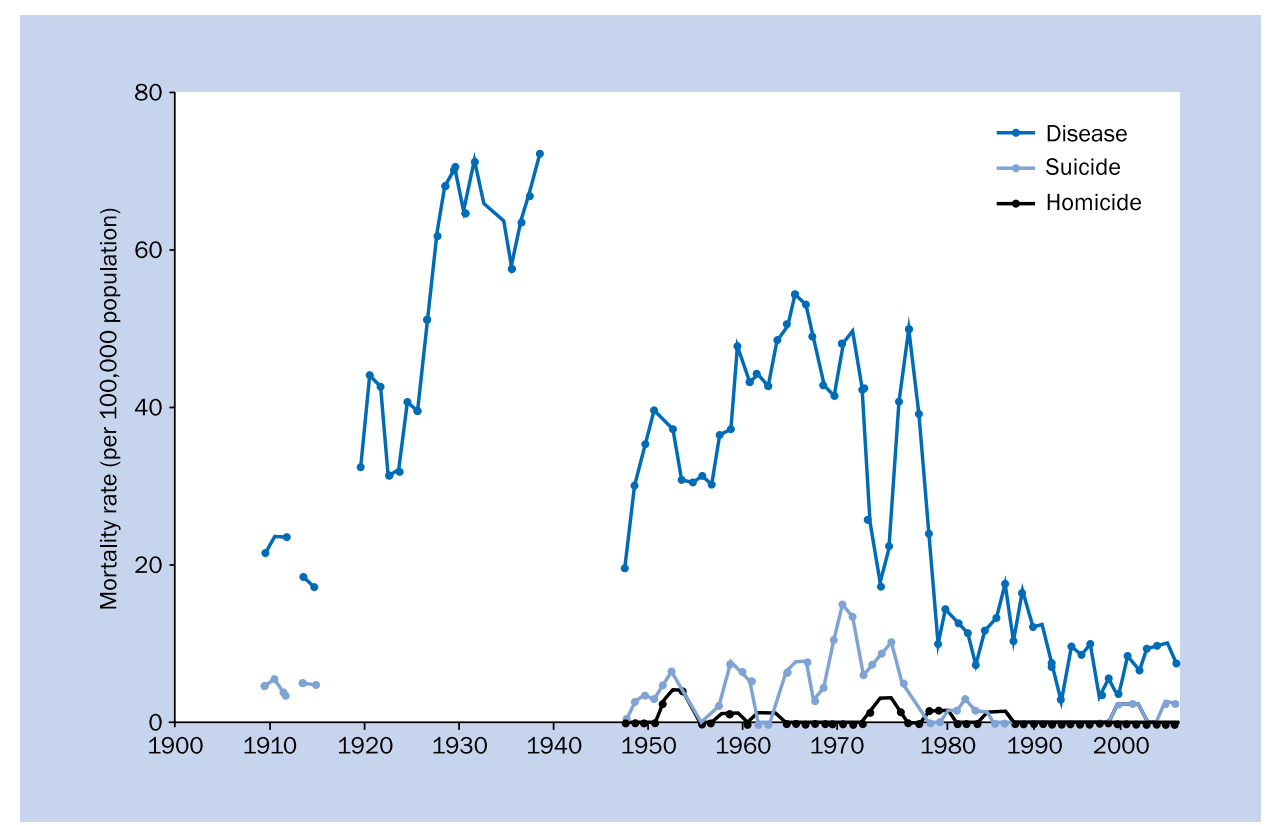

Figure 4. Trends in mortality from disease, suicide and homicide in the British fishing industry. Notes: The mortality rates are smoothed using 3-year moving averages

risks, were adopted and almost certainly reduced loss of life from capsize and foundering.

Although the distant water fleet declined during the late 1970s, there has been no appreciable reduction in the fatal accident rate since. The hazards of distant water fishing in
Arctic conditions have been replaced by a new set of hazards in the British fishing industry; comprising, in recent years, mainly of much smaller fishing vessels with typically fewer crew on board. As reported previously [3], these hazards include a high occurrence of fatalities through the capsize 
of vessels when hauling in gear or through gear snagging on underwater obstructions. Investigations in recent years have also shown that much of the excess mortality is linked to the stability and seaworthiness of smaller fishing vessels. This has often been associated with overloading, poor maintenance and lack of safety equipment [27-29]. There has recently been a marked increase in fatalities arising from the hazardous practice of lone fishing [28, 29], usually personal accidents involving falls overboard. However, evidence on the causes of fishing vessel disasters and loss of life has improved greatly in recent years through the Marine Accident Investigation Branch.

Mortality from disease in the British fishing industry increased to a peak during the late 1930s, it remained high before falling sharply during the late 1970 s, caused largely by the decline of the distant water fishing fleet. The trawlermen were typically at sea for at least 3 or 4 weeks at a time, often operating in severe, stressful and fatiguing Arctic conditions with minimal access to health services. Acute cardiovascular and cerebrovascular diseases account for most disease mortality at sea among fishermen $[2,6,7]$. The high disease mortality during the 1920 s and 1930 s coincided strongly with the expansion of distant water fishing. At this time acute infections were a more common cause of death than in later periods when antibiotics were available and access to radio-medical advice was possible. The much lower disease mortality since the early 1980 s is linked to several factors, including the predominance of coastal fishing, with deaths more likely to be administered and recorded by coroners or shore-based registrars and less often notified with maritime authorities. This time period has also coincided with major reductions over time in the incidence and mortality from major acute diseases in the general population [30].

The suicide rate in the British fishing industry was fairly low and constant at around 5 to 10 per 100,000 over much of the twentieth century but has declined sharply following the collapse of the distance water sector in the late 1970s. The study includes only those suicides among fishermen that occurred while at work. Other studies from Northern Europe that have investigated suicides among fishermen ashore, which would include deaths after discharge through sickness, have identified quite high rates of suicide [31, 32]. There were few homicides in the British fishing industry and most that occurred were during the 1950s and the mid-1970s when there was a large distance water sector.

\section{CONCLUSIONS - KEY MESSAGES}

1. Accidents are the predominant cause of death in sea fishing. Diseases make far smaller contributions, as do suicide and homicide.

2. Accidental deaths may arise from loss of vessels or from severe personal injuries (or drowning) while working on board. Vessel losses contributed a far higher proportion of the deaths in the past than more recently. However some causes of vessel losses, notably instability and snagging on submerged objects, now appear to have become more important.

3. The fishing techniques used and locations of the fisheries both have significant implications for mortality.

4. Distant water fishing in Arctic waters has had a particular set of risks, with multiple fatalities from the loss of large vessels associated with adverse weather conditions and a high case fatality rate for injury and disease because of distance from health care. The cessation of these fisheries has led to a very different pattern of mortality in recent years.

\section{ACKNOWLEDGEMENTS}

The authors are grateful to Cathy Pennock, Audrey Hodges and the Marine Accident Investigation Branch for helpful advice and for providing accident investigation files, the Registry of Shipping and Seamen for providing access to death inquiry files and death registers, Hull Trawler.net and the Marine Accident Investigation Branch for photographs.

\section{REFERENCES}

1. Lincoln JM, O'Connor MB, Retzer KD et al. Occupational fatalities in Alaska: two decades of progress, 1990-1999 and 2000-2009. J Safety Res 2013; 44: 105-110.

2. Roberts SE. Occupational mortality in British commercial fishing, 1976-1995. Occup Environ Med 2004; 61: 16-23.

3. Roberts SE, Jaremin B, Marlow PB. Human and fishing vessel losses in sea accidents in the UK fishing industry from 1948 to 2008. Int Marit Health 2010; 62: 143-153.

4. Laursen LH, Hansen HL, Jensen OC. Fatal occupational accidents in Danish fishing vessels 1989-2005. Int J Inj Contr Saf Promot 2008; 15: 109-117.

5. Petursdottir G, Hjoervar T, Snorrason H. Fatal accidents in the Icelandic fishing fleet 1980-2005. Int Marit Health 2007; 58: 47-58.

6. Aasjord HL. Tools for improving safety management in the Norwegian Fishing Fleet occupational accidents analysis period of 1998-2006. Int Marit Health 2006; 57: 76-84.

7. Jaremin B, Kotulak E, Starnawska M. Comparative study of the death during sea voyages among Polish seamen and deep-sea and boat fishermen. Bull Inst Marit Trop Med Gdynia 1997; 48: 5-22.

8. Jaremin B, Kotulak E. Mortality in the Polish small-scale fishing industry. Occup Med (Lond) 2004; 54: 258-260.

9. Lincoln JM, Lucas DL. Occupational fatalities in the United States commercial fishing industry, 2000-2009. J Agromed 2010; 15 : 343-350.

10. Roberts SE, Nielsen D, Kotłowski A, Jaremin B. Fatal accidents and injuries among merchant seafarers worldwide. Occup Med (Lond) 2014; 64: 259-266.

11. The Merchant Shipping Act, 1894. Eyre and Spottiswoode, London 1894.

12. Board of Trade. Return of Shipping Casualties and Deaths. Vessels Registered in the United Kingdom [annual returns for 1909-1911, 1913, 1914]. HMSO, London 1910-1915. 
13. Board of Trade. Return of Shipping Casualties and Deaths. Vessels Registered in the United Kingdom [annual returns for 1919-1938]. HMSO, London 1920-1939.

14. Ministry of Transport. Return of Shipping Casualties and Deaths: Vessels Registered in the United Kingdom [annual returns for 1948-1963 with summary tables for the years 1939-1947]. HMSO, London 1949-1964.

15. Board of Trade. Shipping Casualties and Deaths: Vessels Registered in the United Kingdom [annual returns for 1964-1968]. HMSO, London 1965-1969.

16. Department of Trade and Industry/Department of Industry/Department of Trade. Shipping Casualties and Deaths: Vessels Registered in the United Kingdom [annual returns for 1969-1975]. HMSO, London 1970-1976.

17. Hull Trawler (www.hulltrawler.net/; last accessed $10^{\text {th }}$ December 2015).

18. Port Cities - Southampton (www.plimsoll.org/; last accessed $10^{\text {th }}$ December 2015).

19. Ships Nostalgia (http://www.shipsnostalgia.com/; last accessed $10^{\text {th }}$ December 2015).

20. Ministry of Agriculture and Fisheries. Sea Fisheries Statistical Tables [annual returns for 1919-1954. HMSO, London 1920-1955.

21. Ministry of Agriculture, Fisheries and Food. United Kingdom Sea Fisheries Statistics [annual returns for 1955-1998]. HMSO, London 1956-1999.
22. Department for Environment, Food and Rural Affairs. United Kingdom Sea Fisheries Statistics [annual returns for 1999-2010]. HMSO, London 2000-2011.

23. Marine Accident Investigation Branch. Sinking of stern trawler Gaul with loss of 36 lives. Marine Accident Investigation Branch, Southampton 1995.

24. Gill A. Lost trawlers of Hull. Hutton Press Ltd, Beverley 1990.

25. O'Driscoll P, Nicklin J. Trawler Disasters 1946-1975: from Aberdeen, Fleetwood, Grimsby and Hull. Amberley Publishing, Stroud 2010.

26. Couper A, Smith HD, Ciceri B. Fishers and Plunderers. Theft, Slavery and Violence at Sea. Pluto Press, London 2015.

27. Marine Accident Investigation Branch. Analysis of UK Fishing Vessel Safety 1992 to 2006. Marine Accident Investigation Branch, Southampton 2008.

28. Marine Accident Investigation Branch. Fishing 2014. Safety Digest. Marine Accident Investigation Branch, Southampton 2014.

29. Marine Accident Investigation Branch. Safety Digest. Lessons from Marine Accidents 2/2015. Marine Accident Investigation Branch, Southampton 2015.

30. Griffiths C, Brock A. Twentieth Century Mortality Trends in England and Wales. Health Stat Q. 2003; 18: 5-17.

31. Stark C, Belbin A, Hopkins P, Gibbs D, Hay A, Gunnell D. Male suicide and occupation in Scotland. Health Stat Q 2006; 29: 26-29.

32. Rafnsson V, Gunnarsdóttir H. Risk of fatal accidents occurring other than at sea among Icelandic seamen. BMJ 1993; 306: 1379-1381. 